\title{
Fluid-rock interaction recorded in black fault rocks in the Kodiak accretionary complex, Alaska
}

\author{
Asuka Yamaguchi ${ }^{1 *}$, Tsuyoshi Ishikawa ${ }^{2}$, Yasuhiro Kato ${ }^{3}$, Tatsuo Nozaki ${ }^{4}$, Francesca Meneghini ${ }^{5,6}$, Christie D Rowe $^{7}$, \\ James Casey Moore ${ }^{5}$, Akito Tsutsumi ${ }^{8}$ and Gaku Kimura ${ }^{9}$
}

\begin{abstract}
Ultrafine-grained black fault rocks (BFRs) in the Pasagshak Point Thrust of the Kodiak accretionary complex are examples of fault rocks that have recorded seismicity along an ancient subduction plate boundary. Trace element concentrations and ${ }^{87} \mathrm{Sr} /{ }^{86} \mathrm{Sr}$ ratios of BFRs and surrounding foliated/non-foliated cataclasites were measured to explore the nature of fluid-rock interactions along a subduction thrust. Foliated and non-foliated cataclasites do not show significant geochemical anomalies, suggesting that they were formed by slowly distributed shear. BFRs are characterized by $\mathrm{Li}$ and $\mathrm{Sr}$ enrichment, $\mathrm{Rb}$ and $\mathrm{Cs}$ depletion, and a $10 \mathrm{w}^{87} \mathrm{Sr} /{ }^{86} \mathrm{Sr}$ ratio. These geochemical signatures can be explained by fluid-rock interactions at $>350^{\circ} \mathrm{C}$, which result in preferential removal of $\mathrm{Rb}$ and $\mathrm{Cs}$ and formation of plagioclase under the presence of fluids with high $\mathrm{Li}$ and $\mathrm{Sr}$ concentrations and low ${ }^{87} \mathrm{Sr} /{ }^{86} \mathrm{Sr}$ ratios. Geochemical anomalies recorded by the BFRs indicate both frictional heating and external fluid influx into the subduction thrust.
\end{abstract}

Keywords: Subduction zone; Seismogenic zone; Pseudotachylyte; Fluid-rock interaction

\section{Findings}

\section{Introduction}

In subduction zones, fluids are abundant due to porosity reduction and dehydration of hydrous minerals. Most of the seismic moments released by global earthquakes occur along subduction zones, where fluids play important mechanical and chemical roles in seismic faulting. From a geological perspective, pseudotachylytes formed by frictional melting during high-velocity seismic slip have classically been considered as the only definitive evidence of earthquakes (Sibson 1975; Cowan 1999). Although occurrences of pseudotachylytes in crystalline continental rocks were known until approximately the 1990s (Swanson 1992), several pseudotachylyte-bearing fault zones in subduction settings have been discovered in recent years (Ikesawa et al. 2003; Kitamura et al. 2005; Rowe et al. 2005, 2011; Mukoyoshi et al. 2006; Okamoto et al. 2006; Meneghini et al. 2010; Hashimoto et al. 2012).

The ultrafine-grained black fault rock (BFR) in the Kodiak accretionary prism, Alaska, was first discovered by Rowe et al. (2005), who considered this rock as an

\footnotetext{
* Correspondence: asuka@aori.u-tokyo.ac.jp

${ }^{1}$ Atmosphere and Ocean Research Institute, the University of Tokyo, 5-1-5 Kashiwanoha, Kashiwa, Chiba 277-8564, Japan

Full list of author information is available at the end of the article
}

example of subduction zone pseudotachylytes. Because BFR is unique in terms of its large thickness (up to $30 \mathrm{~cm}$ ) and widespread occurrence, it has been further investigated on both microscopic (Meneghini et al. 2010) and macroscopic (Rowe et al. 2011) scales. Meneghini et al. (2010) also characterized the geochemistry of fault rocks and detected $\mathrm{Sr}$ anomalies. Here, we describe new geochemical observations that emphasize the role of fluids in the development of BFR.

Anomalies of trace element concentrations and isotope compositions within fault zones have recently been used to estimate maximum fluid temperatures (Ishikawa et al. 2008; Hirono et al. 2009; Hamada et al. 2011; Honda et al. 2011) because trace elements and isotopes can reflect fluid-rock interactions at temperatures as high as approximately $350^{\circ} \mathrm{C}$. The mineralogy of fault zones can also affect element distribution during fluid-rock interactions (Yamaguchi et al. 2011b). Taking these works into consideration, we attempt to reconcile trace element concentrations and $\mathrm{Sr}$ isotope ratios in the ultrafine-grained BFR and surrounding cataclasites in Kodiak Island to gain a better understanding of the role of fluids in faulting. Based on the geochemical result, we interpret these geochemical results in terms of fluid-rock interactions recorded in plate boundary thrusts.

\section{Springer}

(c) 2014 Yamaguchi et al.; licensee Springer. This is an Open Access article distributed under the terms of the Creative Commons Attribution License (http://creativecommons.org/licenses/by/4.0), which permits unrestricted use, distribution, and reproduction in any medium, provided the original work is properly credited. 


\section{Geological setting and occurrences of cataclasites}

The Kodiak archipelago in Alaska (Figure 1a) consists of a Jurassic to Eocene accretionary complex composed of NW-dipping, thrust-bounded units showing progressively younger ages toward the southeast (Moore et al. 1983; Plafker et al. 1994) that are intruded by 58- to 59-Ma near-trench granitic rocks reflecting ridge subduction (Farris et al. 2006; Ayuso et al. 2009). The Ghost Rocks Formation, consisting of the latest Cretaceous-earliest Paleocene ridge-flank deposits, is distributed over the southeastern part of Kodiak Island (Fisher and Byrne 1987). This formation is overthrust by the Late Cretaceous Kodiak Formation and is underthrust by Eocene marine sediments (Moore 1969). The structural base of the Ghost Rocks Formation consists of a tectonic mélange composed of blocks of coherent turbidites and sandstones in a matrix of disrupted mudstones and argillites (Byrne 1982, 1984). Pillow basalts and hyaloclastites showing prehnite-pumpellyite facies metamorphism are included in the matrix (Moore 1969; Byrne 1982).

The Pasagshak Point Thrust (Rowe et al. 2005, 2011; Meneghini et al. 2010) is a strike-parallel fossil thrust zone exposed along the rocky shoreline of Pasagshak Point (Figure 1). The thrust is located within the basal mélange zone of the Ghost Rocks Formation, implying shear localization along an ancient subduction thrust (Rowe et al. 2005). Both the hanging wall and footwall of the thrust consist of mélanges composed of terrigenous sandstones, mudstones, and argillites (Additional file 1: Figure S1a) with minor greenstones. Large sandstone blocks (thickness $>10 \mathrm{~m}$ ) occur in the hanging wall in places. S-C structures, slickenlines, and rotated fold axes within the fault zone suggest a top-to-southeast sense of shear (Rowe et al. 2005, 2011; Meneghini et al. 2010). The paleotemperature of the syn-tectonic fluid is estimated to be $230^{\circ} \mathrm{C}$ to $260^{\circ} \mathrm{C}$ from fluid inclusions in quartz veins within the mélange zone (Vrolijk et al. 1988), whereas the maximum burial temperature of the wall rock is estimated to be $250^{\circ} \mathrm{C} \pm 10^{\circ} \mathrm{C}$ from vitrinite reflectance analysis of carbonaceous material within the argillite (Rowe et al. 2011). The similarity of the two temperature estimates suggests that deformations recorded in the thrust zone occurred at approximately $250^{\circ} \mathrm{C}$ at seismogenic depths of the plate boundary décollement.

Various types of cataclasites, 7 to $31 \mathrm{~m}$ in thickness, occur within the thrust zone (Additional file 1: Figure S1) (Rowe et al. 2011). Detailed structures of cataclastic fault rocks have been described in previous accounts (Rowe et al. 2005, 2011; Meneghini et al. 2010). Cataclastic fault rocks are classified into three categories: foliated cataclasites (both clast-rich and matrix-rich; Additional file 1: Figure S1b), non-foliated cataclasites (Additional file 1: Figure S1c), and ultrafine-grained black fault rocks (BFRs; Additional file 1: Figure S1d). The BFRs, locally

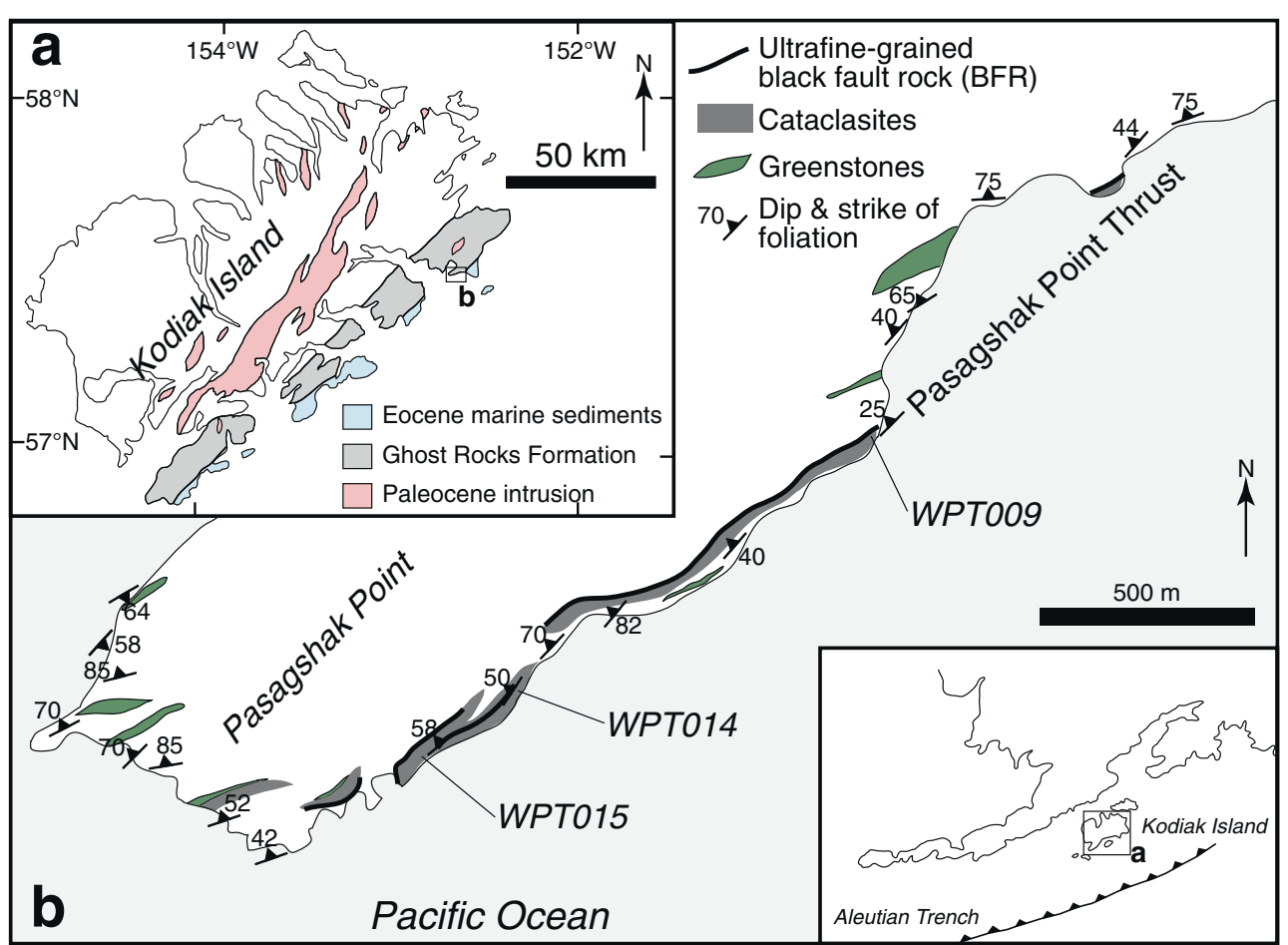

Figure 1 Geological setting of the study area. (a) Ghost Rocks Formation in Kodiak Island. (b) Simplified geological map of the Pasagshak Point Thrust and outcrop localities. 
thicker than $30 \mathrm{~cm}$, make up the principal shear zones in the thrust zone and are further classified into three types: aphanitic, grain-supported, and clast-bearing. The structural features of foliated and non-foliated cataclasites in comparison with the textures formed by experimentation suggest that foliated cataclasites were formed by slow creep (Niemeijer and Spiers 2006), whereas non-foliated cataclasites were formed at faster shear rates, such as through afterslips or delocalized slips associated with earthquakes (Rowe et al. 2011). The aphanitic BFRs contain crystalline microlayers that are regarded as melt-origin microtextures (Meneghini et al. 2010) and are therefore interpreted as pseudotachylytes formed during seismic slip. Conversely, grain-supported BFRs and clast-bearing BFRs are considered to be reworked pseudotachylytes that have mixed with surrounding cataclasites, respectively (Meneghini et al. 2010). BFRs show the greatest biomarker thermal maturity, whereas that of the cataclasites decreases with distance from the BFRs (Savage et al. 2014). BFRs, foliated cataclasites, and non-foliated cataclasites exhibit mutually crosscutting relationships (Additional file 1: Figure S1e) and represent repeated deformations with different strain rates, which may be related to seismic cycles (Rowe et al. 2011).

\section{Geochemical analysis and results}

Samples of two host rocks, six foliated cataclasites, two non-foliated cataclasites, two clast-bearing BFRs, and one aphanitic BFR were selected for geochemical analysis (Additional file 2: Table S1). These samples were collected from three representative outcrops (wpt 009, wpt 014, and wpt 015 of Meneghini et al. 2010; Rowe et al. 2011) and were carefully cut into approximately $10 \mathrm{~mm} \times 10 \mathrm{~mm} \times 10 \mathrm{~mm}$ chips to avoid the influence of surface weathering. The chips were ultrasonicated in deionized water and were then pulverized in an agate ball mill.

Major element concentrations were determined by an X-ray fluorescence spectrometer (XRF; MagiX PRO, Spectris, Egham, Surrey, UK) installed at the Kochi Core Center (KCC), Kochi, Japan, using the conventional glass bead method. Powdered splits for trace elements and isotope analyses were dissolved by $\mathrm{HNO}_{3}-\mathrm{HF}-\mathrm{HClO}_{4}$ digestion and were then evaporated. The residue was dissolved with $\mathrm{HNO}_{3}$ and was diluted to approximately 1:1,000. Concentrations of Sc, $\mathrm{V}, \mathrm{Cr}, \mathrm{Co}, \mathrm{Ni}, \mathrm{Cu}, \mathrm{Zn}, \mathrm{As}$, $\mathrm{Rb}, \mathrm{Sr}, \mathrm{Y}, \mathrm{Zr}, \mathrm{Nb}, \mathrm{Mo}, \mathrm{Cs}, \mathrm{Ba}, \mathrm{La}, \mathrm{Ce}, \mathrm{Pr}, \mathrm{Nd}, \mathrm{Sm}, \mathrm{Eu}, \mathrm{Gd}$, $\mathrm{Tb}, \mathrm{Dy}, \mathrm{Ho}, \mathrm{Er}, \mathrm{Tm}, \mathrm{Yb}, \mathrm{Lu}, \mathrm{Hf}, \mathrm{Ta}, \mathrm{Pb}, \mathrm{Th}$, and $\mathrm{U}$ were determined by an inductively coupled plasma mass spectrometer (ICP-MS; Agilent 7500c, Agilent Technologies, Santa Clara, CA, USA) installed at the Department of Systems Innovation, the University of Tokyo, Tokyo, Japan (Kato et al. 2005). Li, Be, Ti, W, and $\mathrm{Tl}$ concentrations were measured by ICP-MS (ELAN
DRC II, PerkinElmer, Waltham, MA, USA) at the KCC. Sr was separated using ion-exchange resin columns (Sr Resin, Eichrom Technologies Inc., Lisle, IL, USA), and $\mathrm{Sr}$ isotope ratios were determined by thermal ionization mass spectrometry (TIMS; TRITON, Thermo Fisher Scientific, Waltham, MA, USA) at the KCC. The ${ }^{87} \mathrm{Sr} /{ }^{86} \mathrm{Sr}$ value obtained for the NIST SRM 987 standard was $0.7102570 \pm 0.000010$.

Analytical results are shown in Additional file 2: Table S1. Major element and some trace element compositions are consistent with previously reported values as determined by XRF (Meneghini et al. 2010). Element compositions normalized by averaged host rock values are presented in Figure 2. The clast-bearing BFRs and aphanitic BFRs show systematic positive or negative anomalies in some elements such as $\mathrm{Li}$ and $\mathrm{Sr}$ enrichments and $\mathrm{Rb}, \mathrm{Cs}$, and As depletions. Conversely, foliated and non-foliated cataclasites do not show such clear systematic patterns. Sr concentrations in the BFRs are generally high, ranging from 228 to $941 \mathrm{ppm}$, with the highest concentration exhibited in sample 015-10BS (aphanitic BFR). ${ }^{87} \mathrm{Sr} /{ }^{86} \mathrm{Sr}$ ratios are 0.70877 and 0.70922 in the host rocks, 0.70667 to 0.70875 in the foliated and non-foliated cataclasites, and 0.70593 to 0.70627 in the BFRs. The aphanitic BFR exhibits the lowest ${ }^{87} \mathrm{Sr} /{ }^{86} \mathrm{Sr}$ ratio (0.70593).

\section{Discussion}

The trace element composition of the BFRs exhibits tendencies similar to those of principal shear zones of other fault zones reported to possess coseismic fluid-rock interactions (Ishikawa et al. 2008; Hamada et al. 2011; Honda et al. 2011). Enriched and depleted elements in the Kodiak BFR ( $\mathrm{Li}, \mathrm{Rb}, \mathrm{Cs}$, and $\mathrm{Sr}$ ) are known to be fluidly mobile elements easily affected by high-temperature fluid-rock interactions. The trace element concentration in a solid chemically equilibrated with fluid was modeled by Ishikawa et al. (2008) as

$$
C_{\mathrm{s}}=D\left(C_{\mathrm{s} 0}+R C_{\mathrm{f} 0}\right) /(R+D),
$$

where $C_{\mathrm{s} 0}, C_{\mathrm{s}}$, and $C_{\mathrm{f} 0}$ are the element concentrations in the initial solid, solid equilibrated with fluid, and initial fluid, respectively; $R$ is the fluid/solid mass ratio; and $D$ is the temperature-dependent solid/fluid bulk distribution coefficient of the element. In our model analysis, the values for $D$ were estimated by hydrothermal experimental results at $250^{\circ} \mathrm{C}, 300^{\circ} \mathrm{C}$, and $350^{\circ} \mathrm{C}$ using hemipelagic sediments (You et al. 1996; Ishikawa et al. 2008). The values for $C_{\mathrm{fo}}$ and $C_{\mathrm{s} 0}$ are based on the deep pore fluid data from offshore Texas (Kharaka and Hanor 2003) reported by Ishikawa et al. (2008) and averaged host rock, respectively. Figure 3 compares actual BFR composition (red and orange squares and triangles) and calculated fault rock compositions (solid and dashed lines, depending on 


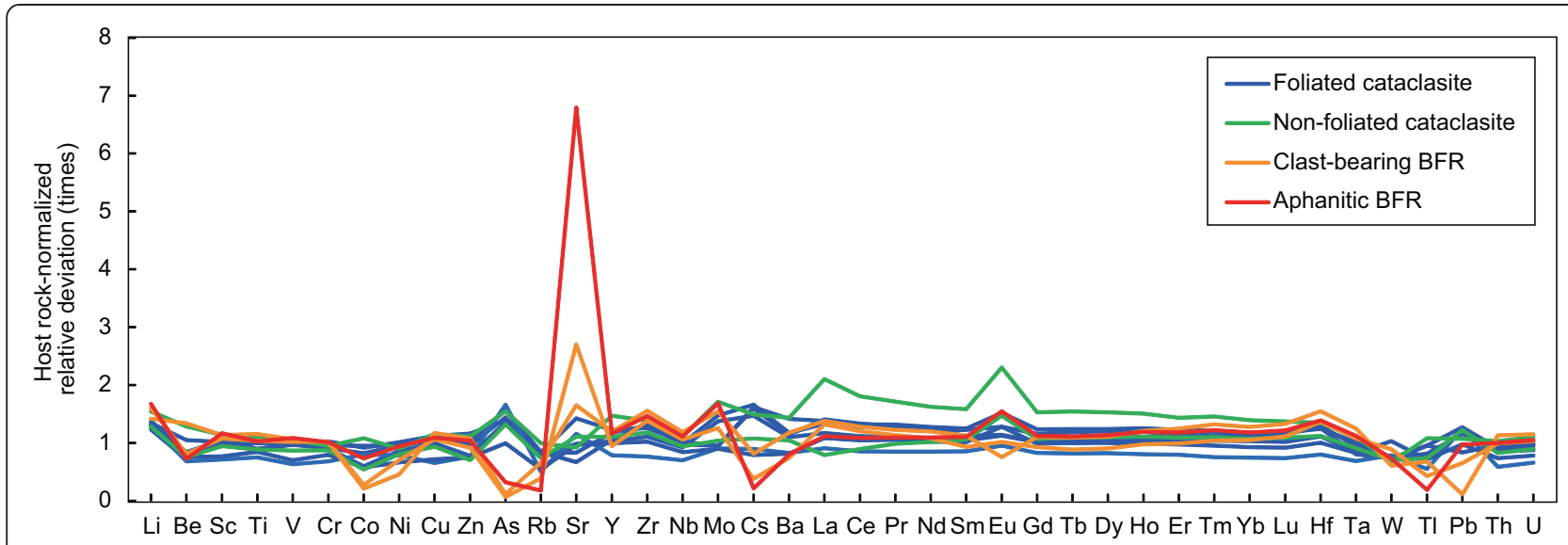

Figure 2 Trace element anomalies of fault rocks normalized by averaged host rock compositions.

$R$ values) of selected trace elements ( $\mathrm{Rb}, \mathrm{Sr}, \mathrm{Cs}, \mathrm{Ba}, \mathrm{La}$, $\mathrm{Sm}$, and $\mathrm{Pb}$ ) at temperatures of $250^{\circ} \mathrm{C}, 300^{\circ} \mathrm{C}$, and $350^{\circ} \mathrm{C}$. The calculations at $T=350^{\circ} \mathrm{C}$ and $R=100$ are closest to the actual trace element compositions of the aphanitic BFR. For the clast-bearing BFR, conditions of $T=350^{\circ} \mathrm{C}$ and $R=10$ or $T=300^{\circ} \mathrm{C}$ and $R=100$ are the most appropriate for reproducing trace element compositions, except for Li. The estimated $R$ values (10 to 100) are significantly higher than those estimated in other fault zones that range from 3 to 7 (Ishikawa et al. 2008; Hamada et al. 2011; Honda et al. 2011). The reasons for this incongruity may be the lack of experimental data for temperatures higher than $350^{\circ} \mathrm{C}$ and that $R$ values of 10 to 100 and $T$ values of $300^{\circ} \mathrm{C}$ to $350^{\circ} \mathrm{C}$ were the maximum and minimum estimations. Alternatively, these results can be explained by a longer fluid residence time and greater duration of high temperatures due to the depth of the Pasagshak Point Thrust. In both cases, our geochemical datasets suggest that the overall composition of the BFR is controlled by fluid-rock interactions at temperatures higher than $350^{\circ} \mathrm{C}$. This temperature is at least $100^{\circ} \mathrm{C}$ higher than the approximately $250^{\circ} \mathrm{C}$ estimated background temperature of the Pasagshak Point Thrust determined by vitrinite reflectance (Rowe et al. 2011) and is only achievable under conditions of coseismic frictional heating. High temperatures recorded in the BFR are consistent with recent results of biomarker thermal maturity (Savage et al. 2014). In contrast to BFR, foliated and non-foliated cataclasites exhibit no high-temperature signals. This is also consistent with the structural interpretation that foliated and nonfoliated cataclasites are formed by slow creep and intermediate strain rate deformation, respectively (Rowe et al. 2011).

$\mathrm{Sr}$ enrichment has been reported in the principal gouge zones of the Taiwan Chelungpu Fault, where it has been regarded as an indicator of plagioclase enrichment (Ishikawa et al. 2008). Ishikawa et al. (2008) concluded that plagioclase was hydrothermally precipitated from high-temperature fluid heated during coseismic frictional slip. Meneghini et al. (2010) reported that the tabular, euhedral, and zoned plagioclase crystals contained in the Pasagshak Point Thrust are enriched in aphanitic BFR. Particularly, in the crystalline microlayers, Ca-rich plagioclase is found only in the BFR. The $\mathrm{Sr}$ enrichment observed in the BFR would reflect the enrichment of plagioclase, as suggested by Meneghini et al. (2010). Based on this interpretation, Sr enrichment is caused by plagioclase microlites crystallized from fluidrich frictional melt. Such an open-system fluid circulation during the formation of pseudotachylytes is also described in an $\mathrm{Rb}-\mathrm{Sr}$ geochronometric study of pseudotachylytes from the North Cascade Mountains (Magloughlin 2003). An alternative possibility is that the $\mathrm{Sr}$ enrichment of the BFR was caused by hydrothermal precipitation of plagioclase from high-temperature fluid, as suggested by Ishikawa et al. (2008). Further detailed layer-by-layer microchemical analyses or Sr chemical mapping is needed to clarify the origin and distribution of $\mathrm{Sr}$ within the BFR because aphanitic BFR is composed of a micrometermillimeter-scale ultrafine layering of granular and crystalline microlayers, which is much finer than the $1-\mathrm{cm}^{3}$ scale of our sampling.

The ${ }^{87} \mathrm{Sr} /{ }^{86} \mathrm{Sr}$ ratio decreases with an increase in $\mathrm{Sr}$ concentration (Figure 4a). This reverse trend implies that the additional $\mathrm{Sr}$ incorporated into rocks with high Sr concentrations had a lower ${ }^{87} \mathrm{Sr} /{ }^{86} \mathrm{Sr}$ ratio $(<0.7059)$ than the host rock, which has ${ }^{87} \mathrm{Sr} /{ }^{86} \mathrm{Sr}$ ratios of 0.7088 to 0.7092 . If we assume that the incorporated $\mathrm{Sr}$ originated from pore fluid that existed during the formation of fault rocks, the fluid would be characterized by a high Sr concentration and low, less radiogenic ${ }^{87} \mathrm{Sr} /{ }^{86} \mathrm{Sr}$ ratio. The observed substantially lower ${ }^{87} \mathrm{Sr} /{ }^{86} \mathrm{Sr}$ ratio $(<0.7059)$ cannot be explained by seawater or terrigenous sediments. Possible candidates for the source of this 

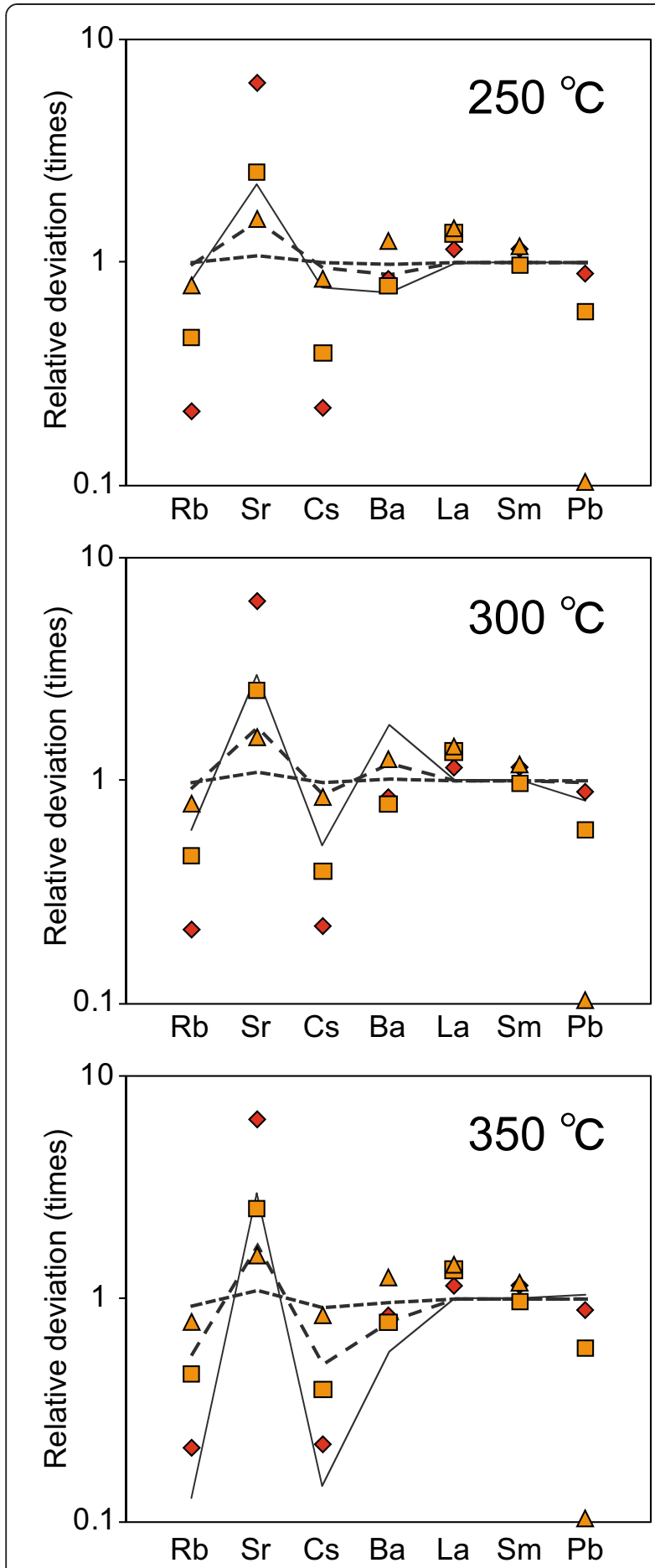

$\diamond \quad$ Aphanitic BFR (015-10BS)

口 Clast-bearing BFR (015-16)

$\Delta$ Clast-bearing BFR (014-3)

----. $\mathrm{R}=1$

$---R=10$

$\mathrm{R}=100$
Figure 3 Comparison of actual BFR composition and calculated fault rock compositions of selected trace elements. Trace element anomalies of black fault rocks (BFRs; red diamonds and orange squares and triangles) and calculated fault rock compositions (solid and dashed lines, depending on $R$ values) of selected trace elements ( $\mathrm{Rb}, \mathrm{Sr}, \mathrm{Cs}, \mathrm{Ba}, \mathrm{La}, \mathrm{Sm}$, and $\mathrm{Pb})$ at temperatures of $250^{\circ} \mathrm{C}$, $300^{\circ} \mathrm{C}$, and $350^{\circ} \mathrm{C}$. The vertical axis shows host rock-normalized relative deviation.

lower ${ }^{87} \mathrm{Sr} /{ }^{86} \mathrm{Sr}$ ratio include hydrated oceanic crust such as the approximately 62-Ma syn-sedimentary mid-ocean ridge basalts (MORBs) in the Ghost Rocks Formation related to ridge subduction (Moore et al. 1983) and subducted oceanic crust. Yamaguchi et al. (2012) detected calcite veins which precipitated from fluids with relatively low ${ }^{87} \mathrm{Sr} /{ }^{86} \mathrm{Sr}$ and large $\delta^{18} \mathrm{O}$ from a paleosubduction thrust in the Shimanto accretionary complex and suggested that fluids dehydrated from the oceanic crust might have acted as the sources of fluids along subduction thrusts. Recently, Sano et al. (2014) reported mantle-derived fluid from seawater at the bottom of the Japan Trench approximately 1 month after the 2011 Tohoku earthquake. Such co- or post-seismic discharges of deep-origin fluid are presumed to have the capability of producing the observed compositional and isotopic anomalies in the BFR.

We observed a negative correlation between the ${ }^{87} \mathrm{Sr} /{ }^{86} \mathrm{Sr}$ ratio and Li concentration (Figure $4 \mathrm{~b}$ ). The Li concentrations of the fault rocks are significantly higher than their simulated values (Figure 3). Li usually shows depletion in the principal shear zones of faults (Ishikawa et al. 2008; Hamada et al. 2011; Honda et al. 2011) because its $D$ value is small at high temperatures. The high concentration of $\mathrm{Li}$ in the fault rocks therefore suggests extremely high concentrations of $\mathrm{Li}$ (approximately 10 to $100 \mathrm{ppm}$ ) in the pore fluid that are $10^{2}$ to $10^{3}$ times more concentrated than that of modern seawater (0.18 ppm; Wunder et al. 2006). The value of $D_{\mathrm{Li}}$ at the background temperature of $250^{\circ} \mathrm{C}$ is low enough to preferentially mobilize Li relative to $\mathrm{Rb}$ and Cs; $D_{\mathrm{Li}}, D_{\mathrm{Rb}}$, and $D_{\mathrm{Cs}}$ values at $250^{\circ} \mathrm{C}$ are 11,290 , and 80 , respectively. The pore fluid that reacted with the BFR could have been significantly enriched in $\mathrm{Li}$ through $\mathrm{Li}$ extraction from the host rocks along the fluid pathways. High Li concentration in fluid along a seismogenic plate boundary thrust would explain the Li-enriched pore water up to $73 \mathrm{ppm}$ discovered at the décollement zone of the Ocean Drilling Program Site 808 near the deformation front of the Nankai Trough (You et al. 1995). Direct measurement of fluid chemistry such as that through fluid inclusion analysis is a possible approach for understanding the geochemical characteristics of fluids existing in the deep portions of plate boundary thrusts.

The Kodiak complex is comparable to the Shimanto accretionary complex in southwest Japan: both complexes 


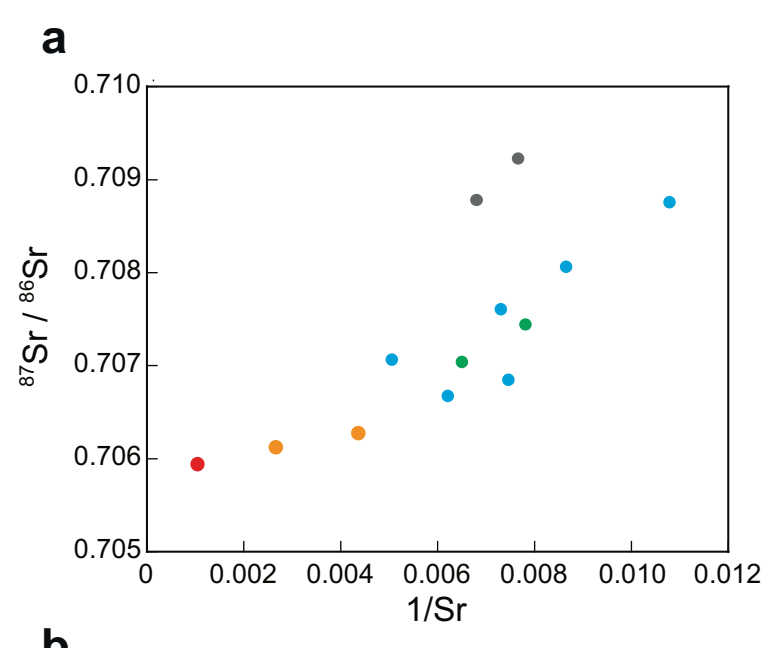

b

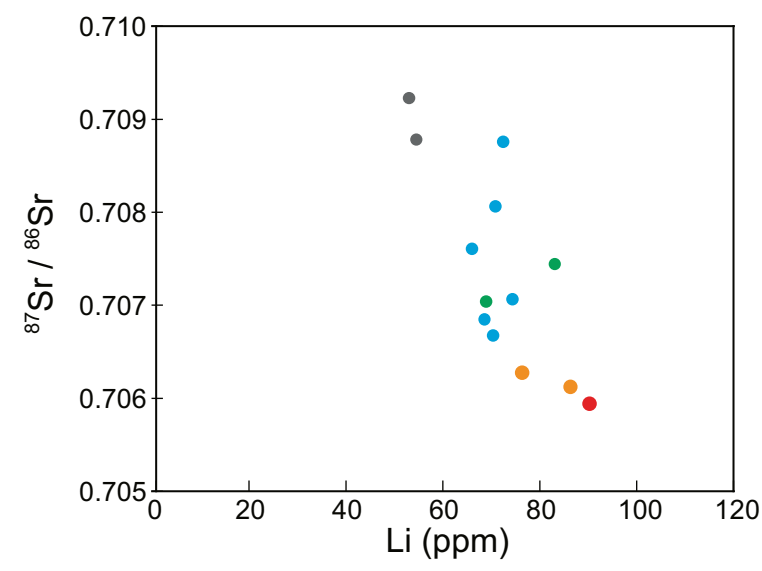

- Aphanitic BFR

- Clast-bearing BFR

- Non-foliated cataclasite

- Foliated cataclasite

- Host rock

Figure $4{ }^{87} \mathrm{Sr} /{ }^{86} \mathrm{Sr}$ ratios of host and fault rocks plotted against (a) $1 / \mathrm{Sr}$ and (b) Li concentrations.

were formed by subduction of a relatively young oceanic plate, and they have similar lithologies characterized by thick terrigenous sediments with rare pelagic sediments. However, the occurrences of fault rock types and fluidrock interaction patterns differ significantly, particularly considering their similar background temperatures (approximately $250^{\circ} \mathrm{C}$ ). In the Shimanto complex, abundant quartz-calcite-ankerite veins are commonly observed along pseudotachylyte- and ultracataclasite-bearing large thrusts (Okitsu mélange: Ikesawa et al. 2003; Mugi mélange: Yamaguchi et al. 2012; Nobeoka Thrust: Okamoto et al. 2006; Yamaguchi et al. 2011a), whereas in the Pasagshak Point Thrust, mineral veins are relatively rare, except for minor quartz shear veins. Instead of mineral veins, plagioclase enrichment may reflect coseismic high-temperature fluid-rock interactions as recognized within the BFR. Such differences in mineralogy and precipitates may reflect variations in regional-scale fluid flow patterns and physicochemical characteristics of fluids along subduction plate boundary interfaces.

\section{Conclusion}

Trace element concentrations and ${ }^{87} \mathrm{Sr} /{ }^{86} \mathrm{Sr}$ ratios of fault rocks in the Pasagshak Point Thrust reflect fluid-rock interactions related to coseismic slip along an ancient subduction thrust. Sampled BFRs are characterized by $\mathrm{Li}$ and $\mathrm{Sr}$ enrichment, $\mathrm{Rb}$ and $\mathrm{Cs}$ depletions, and low ${ }^{87} \mathrm{Sr} /{ }^{86} \mathrm{Sr}$ ratios. Such geochemical signatures can be explained by plagioclase formation at temperatures higher than $350^{\circ} \mathrm{C}$ or the presence of a fluid with high $\mathrm{Li}$ and $\mathrm{Sr}$ concentrations and low ${ }^{87} \mathrm{Sr} /{ }^{86} \mathrm{Sr}$ ratios. The geochemical anomalies of the BFRs therefore suggest both frictional heating and influx of external fluid in a subduction thrust. In contrast to the BFRs, foliated and non-foliated cataclasites do not exhibit significant geochemical anomalies, suggesting that they were formed by slow deformation without large frictional heat or largescale fluid flow. Further geochemical and comparative investigations are necessary to explore the nature of fluids along seismogenic subduction plate boundaries.

\section{Additional files}

Additional file 1: Figure S1. Occurrences of fault rocks in the Pasagshak Point Thrust. (a) Host argillite. (b) Matrix-rich foliated cataclasite. (c) Non-foliated cataclasite including $\delta$-shaped sandstone blocks and fragments of black fault rock (BFR). (d) Occurrence of BFRs. BFR-aph, BFR-grs, and BFR-clb, which indicate aphanitic BFR, grain-supported BFR, and clast-bearing BFR, respectively. (e) Schematic illustration showing the occurrences and crosscutting relationships of the fault rocks.

Additional file 2: Table S1. Major and trace element concentrations and ${ }^{87} \mathrm{Sr} /{ }^{86} \mathrm{Sr}$ ratios of host and fault rocks.

\section{Competing interests}

The authors declare that they have no competing interests.

\section{Authors' contributions}

AY conducted the field survey, geochemical analysis, and paper writing. TI contributed to inductively coupled plasma mass spectrometry (ICP-MS) and thermal ionization mass spectrometry (TIMS) analyses for trace elements and Sr isotopes. YK and TN contributed to ICP-MS analyses for trace elements. JCM, CDR, FM, and AT conducted the field survey and sample/data collection. GK designed the overall research project. All authors read and approved the final manuscript.

\section{Acknowledgements}

This manuscript was improved by the constructive comments of two anonymous reviewers. Discussions with Y. Nishio, K. Ujiie, Y. Sano, M. Toriumi, T. Seno, J. Ashi, J. Kameda, and Y. Hamada were of great benefit in clarifying our concepts. O. Tadai and K. Nagaishi assisted with XRF and ICP-MS analyses at the KCC. This research was financially supported by a Grant-in-Aid for JSPS Fellows Grant Number 06 J11448; JSPS and MEXT KAKENHI Grant Numbers 22107505, 18340155, 21107001, and 21107005; the Plate Dynamics Program of the Japan Agency for Marine-Earth Science and Technology; and the 21st Century Center of Excellence Program of the University of Tokyo. Field work in Alaska was supported by the US National Science Foundation Grant OCE-054901 T-01. 


\section{Author details}

${ }^{1}$ Atmosphere and Ocean Research Institute, the University of Tokyo, 5-1-5 Kashiwanoha, Kashiwa, Chiba 277-8564, Japan. ${ }^{2}$ Kochi Institute for Core Sample Research, Japan Agency for Marine-Earth Science and Technology (JAMSTEC), Nankoku 783-8502, Japan. ${ }^{3}$ Department of Systems Innovation School of Engineering, the University of Tokyo, Tokyo 113-0033, Japan. ${ }^{4}$ Research and Development (R\&D) Center for Submarine Resources, Japan Agency for Marine-Earth Science and Technology (JAMSTEC), Yokosuka 237-0061, Japan. ${ }^{5}$ Earth and Planetary Sciences Department, University of California Santa Cruz, Santa Cruz, CA 95064, USA. ${ }^{\circ}$ Departamento de Geologia, Campus do Morro do Cruzeiro, Universidade Federal de Ouro Preto, Ouro Preto MG 35400-000, Brazil. 'Earth and Planetary Sciences Department, McGill University, Montreal, QC H3A 0E8, Canada. ${ }^{8}$ Department of Geology and Mineralogy, Division of Earth and Planetary Sciences, Graduate School of Science, Kyoto University, Kyoto 606-8502, Japan. ${ }^{9}$ Department of Earth and Planetary Science, the University of Tokyo, Tokyo 113-0033, Japan.

\section{Received: 28 February 2014 Accepted: 4 June 2014}

Published: 19 June 2014

\section{References}

Ayuso RA, Haeussler PJ, Bradley DC, Farris DW, Foley NK, Wandless GA (2009) The role of ridge subduction in determining the geochemistry and $\mathrm{Nd}-\mathrm{Sr}-\mathrm{Pb}$ isotopic evolution of the Kodiak batholith in southern Alaska. Tectonophysics 464:137-163

Byrne T (1982) Structural evolution of coherent terranes in the Ghost Rocks Formation, Kodiak Islands, Alaska. In: Leggett JK (ed) Trench-forearc geology. Trench-forearc geology: sedimentation and tectonics on modern and ancient active plate margins, vol 10. Boulder, pp 229-242

Byrne T (1984) Early deformation in mélange terranes of the Ghost Rocks Formation, Kodiak Islands, Alaska. In: Raymond LA (ed) Mélanges: their nature, origin and significance, vol 198. Geological Society of America Special Paper, pp 21-52

Cowan DS (1999) Do faults preserve a record of seismic slip? A field geologist's opinion. J Struct Geol 21:995-1001

Farris DW, Haeussler PJ, Friedman R, Paterson S, Saltus R, Ayuso R (2006) Emplacement of the Kodiak batholith and slab-window migration. Geol Soc Am Bull 118:1360-1376

Fisher D, Byrne T (1987) Structural evolution of underthrusted sediments, Kodiak Islands, Alaska. Tectonics 6:775-793

Hamada Y, Hirono T, Ishikawa T (2011) Coseismic frictional heating and fluid-rock interaction in a slip zone within a shallow accretionary prism and implications for earthquake slip behavior. J Geophys Res 116, B01302, doi:10.1029/2010JB007730

Hashimoto Y, Eida M, Kirikawa T, lida R, Takagi M, Furuya N, Nikaizo A, Kikuchi T, Yoshimitsu $T$ (2012) Large amount of fluid migration around shallow seismogenic depth preserved in tectonic mélange: Yokonami mélange, the Cretaceous Shimanto Belt, Kochi, Southwest Japan. Island Arc 21:53-64

Hirono T, Ujiie K, Ishikawa T, Mishima T, Hamada Y, Tanimizu M, Soh W, Kinoshita M (2009) Estimation of temperature rise in a shallow slip zone of the megasplay fault in the Nankai Trough. Tectonophysics 478:215-220

Honda G, Ishikawa T, Hirono T, Mukoyoshi H (2011) Geochemical signals for determining the slip-weakening mechanism of an ancient megasplay fault in the Shimanto accretionary complex. Geophys Res Lett 38, L06310, doi:10.1029/2011GL046722

Ikesawa E, Sagaguchi A, Kimura G (2003) Pseudotachylyte from an ancient accretionary complex: evidence for melt generation during seismic slip along a master décollement? Geology 31:637-640

Ishikawa T, Tanimizu M, Nagaishi K, Matsuoka J, Tadai O, Sakaguchi M, Hirono T, Mishima T, Tanikawa W, Lin W, Kikuta H, Soh W, Song SR (2008) Coseismic fluid-rock interactions at high temperatures in the Chelungpu fault. Nat Geosci 1:679-683

Kato Y, Fujinaga K, Suzuki K (2005) Major and trace element geochemistry and Os isotopic composition of metalliferous umbers from the Late Cretaceous Japanese accretionary complex. Geochem Geophys Geosys 6, Q07004, doi:10.1029/2005GC000920

Kharaka YK, Hanor JS (2003) Deep fluids in the continents: I. Sedimentary basins. In: Drever JI (ed) Treatise on geochemistry, vol 5. Elsevier, Amsterdam, pp 499-540

Kitamura Y, Sato K, Ikesawa E, Ikehara-Ohmori K, Kimura G, Kondo H, Ujiie K, Onishi CT, Kawabata K, Hashimoto Y, Mukoyoshi H, Masago H (2005) Mélange and its seismogenic roof décollement: a plate boundary fault rock in the subduction zone-an example from the Shimanto belt, Japan. Tectonics 24 TC5012, doi:10.1029/2004TC001635

Magloughlin JF (2003) An evaluation of Rb-Sr dating of pseudotachylyte: structural-chemical models and the role of fluids. Geochem J 37:21-33

Meneghini F, Di Toro G, Rowe CD, Moore JC, Tsutsumi A, Yamaguchi A (2010) Record of mega-earthquakes in subduction thrusts: the black fault rocks of Pasagshak Point (Kodiak Island, Alaska). Geol Soc Am Bull 122:1280-1297

Moore GW (1969) New formations on Kodiak and adjacent islands, Alaska. U.S. Geological Surv Bull 1274-A:A27-A35

Moore JC, Byrne T, Plumley PW, Reid M, Gibbons H, Coe RS (1983) Paleogene evolution of the Kodiak Islands, Alaska: consequences of ridge-trench interaction in a more southerly latitude. Tectonics 2:265-293

Mukoyoshi H, Sakaguchi A, Otsuki K, Hirono T, Soh W (2006) Co-seismic frictiona melting along an out-of-sequence thrust in the Shimanto accretionary complex: implications on the tsunamigenic potential of splay faults in modern subduction zones. Earth Planet Sci Lett 245:330-343

Niemeijer AR, Spiers CJ (2006) Velocity dependence of strength and healing behaviour in simulated phyllosilicate-bearing fault gouge. Tectonophysics 427:231-253

Okamoto S, Kimura G, Takizawa S, Yamaguchi H (2006) Earthquake fault rock indicating a coupled lubrication mechanism. Earth 1:23-28

Plafker G, Moore JC, Winkler GR (1994) Geology of the southern Alaska margin, chapter 12. In: Plafker G, Berg HC (eds) The geology of Alaska. The geology of North America, G-1. Geological Society of America, Boulder, pp 389-449

Rowe CD, Moore JC, Meneghini F, McKiernan AW (2005) Large-scale pseudotachylytes and fluidized cataclasites from an ancient subduction thrust fault. Geology 33:937-940

Rowe CD, Meneghini F, Moore JC (2011) Textural record of the seismic cycle: strain-rate variation in an ancient subduction thrust. In: Fagereng A, Toy VG, Rowland JV (eds) Geology of the earthquake source: a volume in honour of Rick Sibson, vol 359. Geological Society, London, pp 77-95

Sano Y, Hara T, Takahata N, Kawagucci S, Honda M, Nishio Y, Tanikawa W, Hasegawa A, Hattori K (2014) Helium anomalies suggest a fluid pathway from mantle to trench during the 2011 Tohoku-Oki earthquake. Nat Commun 5:3084, doi:10.1038/ncomms4084

Savage HM, Polissar PJ, Sheppard R, Rowe CD, Brodsky EE (2014) Biomarkers heat up during earthquakes: new evidence of seismic slip in the rock record. Geology 42:99-102

Sibson RH (1975) Generation of pseudotachylyte by ancient seismic faulting. Geophys J Roy Astron Soc 43:775-794

Swanson MT (1992) Fault structure, wear mechanisms and rupture processes in pseudotachylyte generation. Tectonophysics 204:223-242

Vrolijk P, Myers G, Moore JC (1988) Warm fluid migration along tectonic mélanges in the Kodiak accretionary complex, Alaska. J Geophys Res 93:10313-10324

Wunder B, Meixner A, Romer RL, Heinrich W (2006) Temperature-dependent isotopic fractionation of lithium between clinopyroxene and high-pressure hydrous fluids. Contrib Mineral Petrol 151:112-120

Yamaguchi A, Cox SF, Kimura G, Okamoto S (2011a) Dynamic changes in fluid redox state associated with episodic fault rupture along a megasplay fault in a subduction zone. Earth Planet Sci Lett 302:369-377

Yamaguchi A, Sakaguchi A, Sakamoto T, lijima K, Kameda J, Kimura G, Ujiie K, Chester FM, Fabbri O, Goldsby D, Tsutsumi A, Li C-F, Curewitz D (2011b) Progressive illitization in fault gouge caused by seismic slip propagation along a megasplay fault in the Nankai Trough. Geology 39:995-998

Yamaguchi A, Ujiie K, Nakai S, Kimura G (2012) Sources and physicochemical characteristics of fluids along a subduction-zone megathrust: a geochemical approach using syn-tectonic mineral veins in the Mugi mélange, Shimanto accretionary complex. Geochem Geophys Geosyst 13:Q0AD24, doi:10.1029/2012GC004137

You C-F, Chan LH, Spivack AJ, Gieskes JM (1995) Lithium, boron, and their isotopes in sediments and pore waters of Ocean Drilling Program Site 808, Nankai Trough: implications for fluid expulsion in accretionary prisms. Geology 23:37-40

You C-F, Castillo PR, Gieskes JM, Chan LH, Spivack AJ (1996) Trace element behavior in hydrothermal experiments: implication for fluid processes at shallow depths in subduction zones. Earth Planet Sci Lett 140:41-52

\section{doi:10.1186/1880-5981-66-58}

Cite this article as: Yamaguchi et al:: Fluid-rock interaction recorded in black fault rocks in the Kodiak accretionary complex, Alaska. Earth, Planets and Space 2014 66:58. 